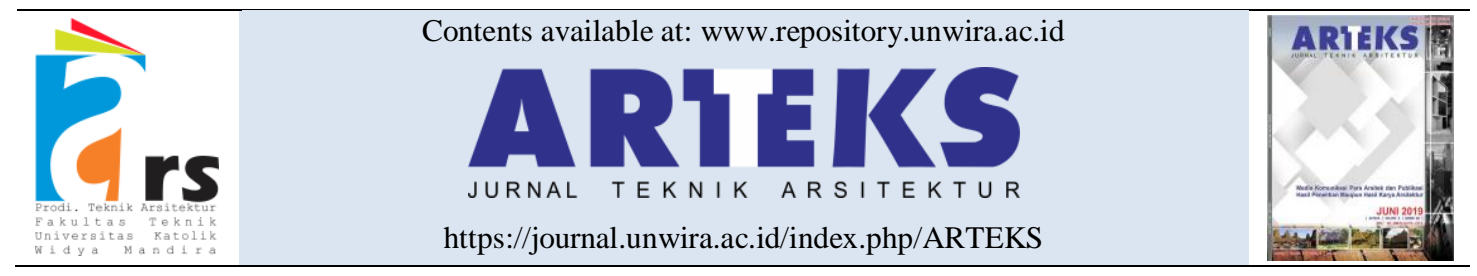

Research paper

doi: 10.30822/arteks.v5i2.395

\title{
Pemetaan hasil penelitian atap hijau dalam disiplin ilmu arsitektur di Indonesia
}

\author{
Sri Yuliani ${ }^{1 *(1)}$, Gagoek Hardiman ${ }^{2}$, Erni Setyowati ${ }^{3}$ \\ ${ }^{1}$ Program Studi Arsitektur, Fakultas Teknik, Universitas Sebelas Maret \\ Jl. Ir. Sutami, no. 36A, Surakarta, Indonesia \\ ${ }^{2,3}$ Program Doktor Ilmu Arsitektur dan Perkotaan, Fakultas Teknik, \\ Universitas Diponegoro, Jl. Prof. Soedarto, SH Tembalang-Semarang 50275, Indonesia
}

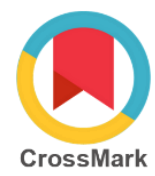

\begin{tabular}{l}
\hline ARTICLE INFO \\
\hline Article history: \\
Received February 19, 2020 \\
Received in revised form March 08, \\
2020 \\
Accepted April 18, 2020 \\
Available online August 01, 2020 \\
\hline
\end{tabular}

Keywords:
Architectural research
Green roof research
Research mapping

ABSTRACT

Research of green roof based on architectural science in Indonesia

Green roof research has developed in a variety of disciplines worldwide. However, research information on the theme of green roofs in Indonesia is still limited, including from the architectural discipline. Therefore, it is very important to identify green roof research mapping from an architectural point of view. The research objective is to identify the novelty of green roof research that has the opportunity to be conducted in Indonesia. The research method using a literature review based on mapping through Vosviewer is followed by analyzing the contents of a number of theories that have been pursed. The results of the study concluded that the study of green roofs from an architectural point of view, still has the opportunity to study using climate-based location parameters and density criteria, function of residential objects, material innovation

*Corresponding author: Sri Yuliani Program Studi Arsitektur, Fakultas Teknik, Universitas Sebelas Maret, Indonesia

Email: sriyuliani71@staff.uns.ac.id

ORCID: https://orcid.org/0000-0002-4288-

2959

\section{Pendahuluan}

Penelitian atap hijau telah banyak menghasilkan temuan referensi untuk pelbagai bidang disiplin ilmu, diantaranya bidang lingkungan (Agra, Klein, Vasl, Shalom, et al. 2017; Hellmeister and Richins 2019; Yang et al. 2018; M. A. Hossain et al. 2019). Dalam ilmu arsitektur, penelitian atap hijau mulai berkembang dengan ekplorasi manfaat pada pengelolaan energi bangunan dan lingkungan (Morakinyo et al. 2017; 2019; M. F. Hossain 2018). Berdasarkan potret konsumsi energi dunia, bidang arsitektur menunjukkan sektor yang mengkonsumsi kebutuhan energi tertinggi dibandingkan dengan bidang lain di seluruh dunia. Banyak karya arsitektural yang menggunakan suplai energi tinggi dalam operasional bangunan, diantaranya untuk pengkondisian udara, kenyamanan visual dan penggunaan teknologi bangunan. Data konsumsi energi dunia yang dipublikasikan oleh U.S. Energy Information Administration pada World Energy Demand and Economic Outlook EIA's Handling of Non-U.S. Policies in The International Energy Outlook 2016 mencatat bahwa total konsumsi energi dunia meningkat 48\% dari tahun 2012 hingga 2040 (U.S. Energy Information Administration 2016). Konsumsi energi terbanyak digunakan pada sektor bangunan, mencakup tidak hanya bangunan komersial namun juga bangunan untuk hunian. Negara-negara di wilayah Asia termasuk Indonesia ternyata memiliki kecenderungan membutuhkan konsumsi energi yang semakin 
meningkat, bahkan tertinggi di banding negara di benua lain (Subroto 2019; Widodo 2019). Pertumbuhan penduduk yang semakin tinggi akan berdampak meningkatkan kebutuhan hunian.

Potret konsumsi energi di Indonesia, memiliki kecenderungan yang hampir sama dengan dunia, dimana sektor bangunan berada pada tingkat konsumsi tertinggi (U.S. Energy Information Administration 2016). Demikian juga halnya dengan pembangunan yang mereduksi area hijau di Indonesia semakin tinggi. Bahkan, hutan Kalimantan diyakini bakal menyusut sebanyak 75\% pada 2020 jika laju deforestasi tidak dihentikan (World Wildlife Fund 2016). Peringatan tersebut didengungkan kembali oleh World Wildlife Fund dalam laporan tahunannya yang dipublikasikan oleh WWF Indonesia dan Malaysia pada tahun 2018.

Indonesia merupakan daerah iklim tropis yang mempunyai potensi keragaman hayati dengan tanah yang subur dan iklim yang bersahabat, sehingga berpeluang mendukung upaya pengelolaan energi bangunan secara efisien (Yuliani, Hardiman, and Setyowati 2018). Namun, seiring dengan populasi penduduk yang semakin meningkat, lahan pertanian produktif sebagai ruang hijau pun kian tereduksi. Pembangunan infrastruktur dan permukiman sangat pesat dan mengurangi area pertanian. Dalam pandangan ilmu arsitektur, fenomena ini memunculkan konsep membangun berbasis arsitektur hijau. Teori arsitektur hijau secara umum, mendesain dengan memanfaatkan potensi iklim, termasuk bagaimana mengelola potensi iklim dengan keterbatasan lahan yang diakomodasi pada bangunan hijau.

Konsep desain arsitektur hijau diantaranya juga menghadirkan unsur alam dalam menyelenggarakan bangunan (Darko and Chan 2018). Unsur alam meliputi potensi-potensi bermanfaat yang dapat menjadi seperangkat daya dukung operasional bangunan yakni angin, sinar matahari, iklim yang bersahabat dan tanaman (Pradono 2019). Tanaman akan menjadi komponen yang dapat membantu mereduksi panas dalam sistem bangunan yang tepat, salah satunya melalui atap bangunan (Morakinyo et al. 2017; Francis and Jensen 2017).

Secara empiris, di Indonesia, telah terdapat beberapa bangunan gedung dengan atap hijau, namun penelitian atap hijau belum banyak dilakukan di Indonesia, terutama untuk sektor hunian. Sedangkan atap hijau mempunyai manfaat yang strategis untuk energi bangunan dan perbaikan kualitas lingkungan. Secara teoritis, penelitian atap hijau harus menyesuaikan dengan kondisi iklim, namun penelitian atap hijau di daerah tropis lembab masih sangat sedikit. Untuk itu, diperoleh permasalahan penelitian yakni bagaimana jejak penelitian atap hijau di Indonesia, sehingga diperoleh peluang riset untuk dikembangkan sesuai kebutuhan masyarakat Indonesia.

Tujuan penelitian adalah menemukan kebaruan penelitian atap hijau di Indonesia. Manfaat penelitian adalah memberikan gambaran dinamika penelitian atap hijau di Indonesia agar bangunan mempunyai kontribusi pada perbaikan lingkungan, baik lingkungan mikro maupun kualitas kesehatan ruangan dalam bangunan.

\section{Metode penelitian}

Penelitian mempunyai ruang lingkup ontologi dalam pembahasan ilmu arsitektur yang secara spesifik membahas bidang sains bangunan melalui arsitektur hijau dengan fokus penelitian pada atap hijau. Berangkat dari latar belakang tujuan pembangunan berkelanjutan, maka penelitian berupaya menemukan jejak riset (Sudradjat 2020) atap hijau yang dapat menjadi acuan penelitian atap hijau berbasis arsitektur di Indonesia.

Metode penelitian menggunakan kajian teoritikal yang bersumber dari jurnal internasional terindex Scopus dengan batasan tahun 2014 hingga 2019 dengan batasan lima bidang kajian meliputi environment, engineering agricultural and biological science, social ciense dan energy. Teori-teori dihimpun melalui penelusuran software vosviewer yakni tools untuk mendata manuskrip online berbasis java script. Vosviewer dapat memvisualkan pola hubungan antar bibliografi, diantaranya berisi data manuskrip yakni judul, pengarang, penulis, tahun dan nama jurnal. Penelusuran dengan metode digital ini dipertajam dengan menggunakan batasan judul dan abstrak yang ada pada menu vosviewer untuk melakukan pemetaan teori atap hijau yang telah dipublikasikan.

Pemetaan teori yang telah diperoleh melalui tool vosviewer selanjutnya menjadi acuan untuk melakukan analisis konten secara detil untuk memperoleh data akurat dari setiap temuan penelitian. 


\section{Temuan dan pembahasan}

Hasil dokumen penelitian atap hijau pada jurnal terindex scopus melalui www.scopus.com diperoleh 3.693 dokumen yang belum dilakukan batasan. Dokumen yang diperoleh perlu difilter agar mendapatkan jejak teori yang lebih mengerucut ke disiplin ilmu arsitektur, yakni dengan batasan lima disiplin ilmu meliputi environmental science, engineering, social science, agricultural \& biological science, dan energy, hingga diperoleh sejumlah 1.935 dokumen.

VOSviewer

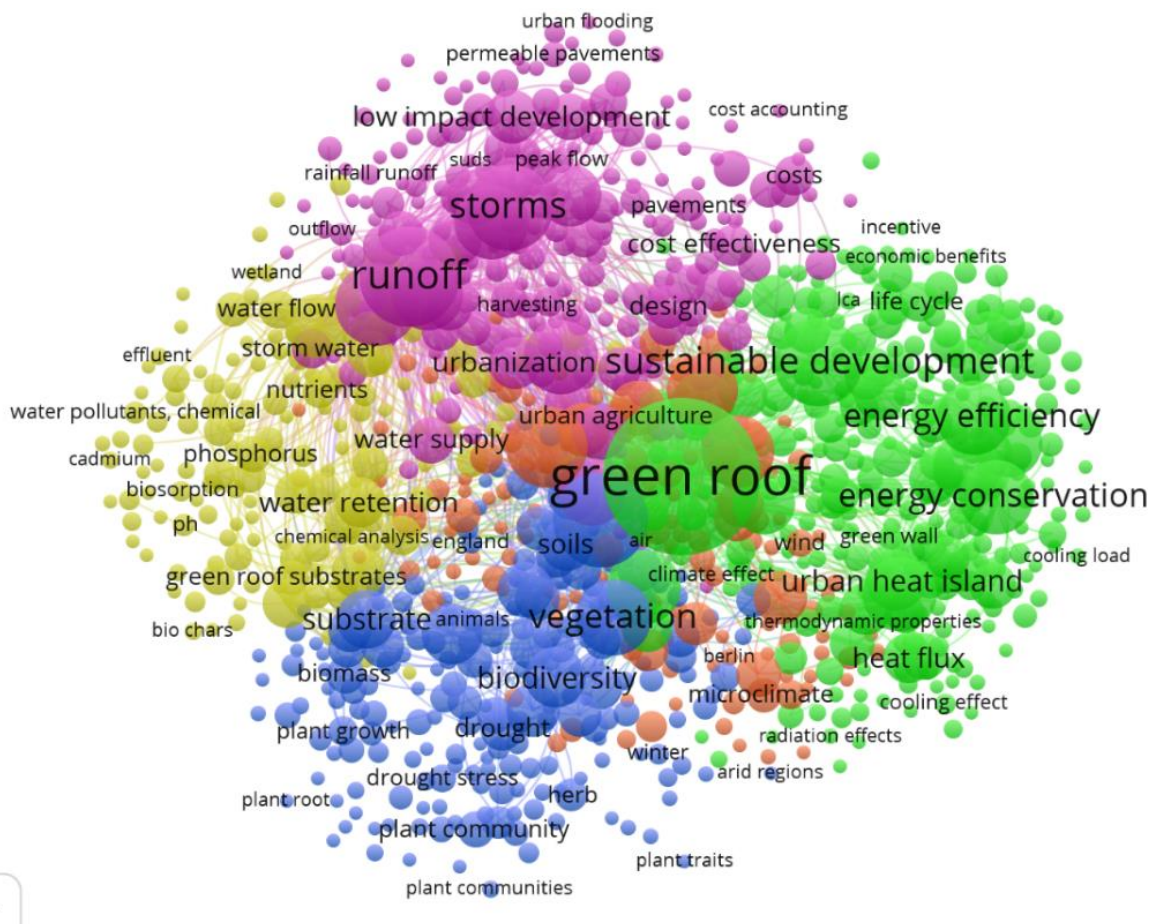

Gambar 1. Network, pola hubungan riset atap hijau dengan vosviewer berdasarkan kata kunci untuk dokumen tahun 2014-2019

Sumber: scopus.com melalui vosviewer

Visualisasi secara detil teori-teori yang ditemukan dalam penelitian atap hijau dengan vosviewer seperti ditunjukkan pada gambar 1 terlihat detil kata kunci yang menjadi pembahasan pada artikel yang dipublikasikan.

Pada gambar 1, ada kumpulan lima warna yang menandakan terdapat lima kluster. Kluster pertama, warna hijau yakni penelitian atap hijau yang berhubungan dengan efisiensi energi, dan pembangunan berkelanjutan. Kluster kedua berwarna merah muda, merupakan penelitian atap hijau terkait upaya pengaturan limpahan air hujan melalui low impact development. Kluster ketiga, warna biru yakni penelitian yang fokus pada penyediaan ruang hijau untuk diversitas. Kluster keempat, kelompok bahasan berwarna kuning, dengan fokus penelitian yang didominasi pada permasalahan perlindungan lingkungan ekologis.
Kelompok kelima berwarna merah, lebih berorientasi pada penelitian atap hijau yang relevan dengan permasalahan urban planning dan perubahan iklim kawasan.

Kelima kluster didominasi oleh kluster pertama yang mencakup penelitian atap hijau pada pembahasan pembangunan berkelanjutan secara ekologis. Hubungan diantara kluster dan setiap dokumen dari jurnal divisualkan dari kedekatan jarak seperti pada gambar 1. Isu energi dan bangunan tetap masih terlihat jelas walaupun tidak sebanyak bidang ekologi. Secara detil dapat dijelaskan bahwa penelitian atap hijau memberikan banyak temuan di bidang ekologi terkait pengelolaan air, dampak lingkungan dan ekosistem. Sedangkan temuan di bidang energi dan bangunan, penelitian menghasilkan temuan terkait konservasi energi bangunan dan panas. 
Kedua bidang tersebut saling mengkait dengan titik fokus yang berbeda sehingga temuan dapat saling mengisi.

Analisis pada vosviewer dalam visualisasi overlay gambar 2 , menunjukkan pemetaan yang hampir sama pada network visualization. Perbedaan visualisasi ini terletak pada jumlah dokumen yang dikutip oleh penelitian yang lain. Warna biru yang senada didominasi pembahasan penelitian atap hijau yang berkaitan dengan pembangunan berkelanjutan, penataan kawasan, konservasi energi dan pelestarian lingkungan.

\& Vosviewer

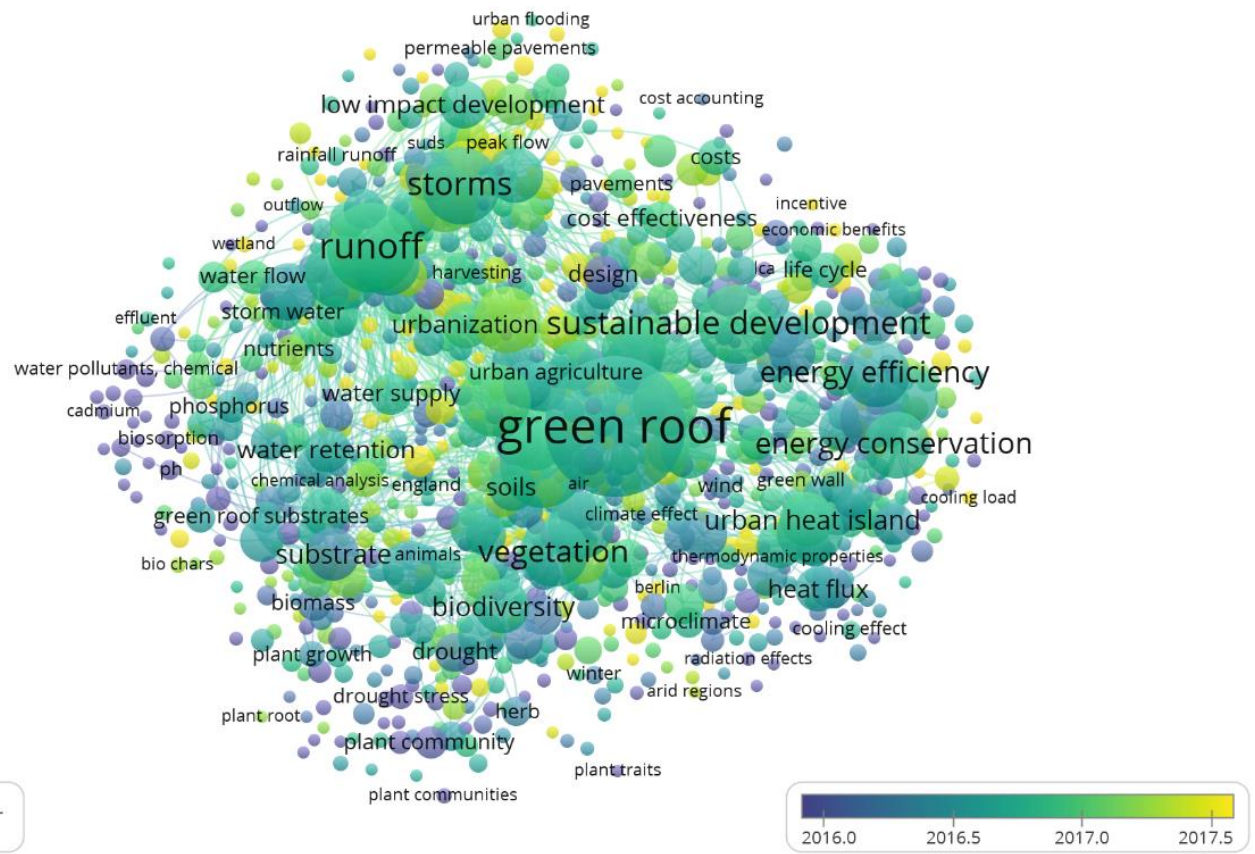

Gambar 2. Overlay, visualisasi terhadap tingkat pembahasan dokumen secara kuantitas

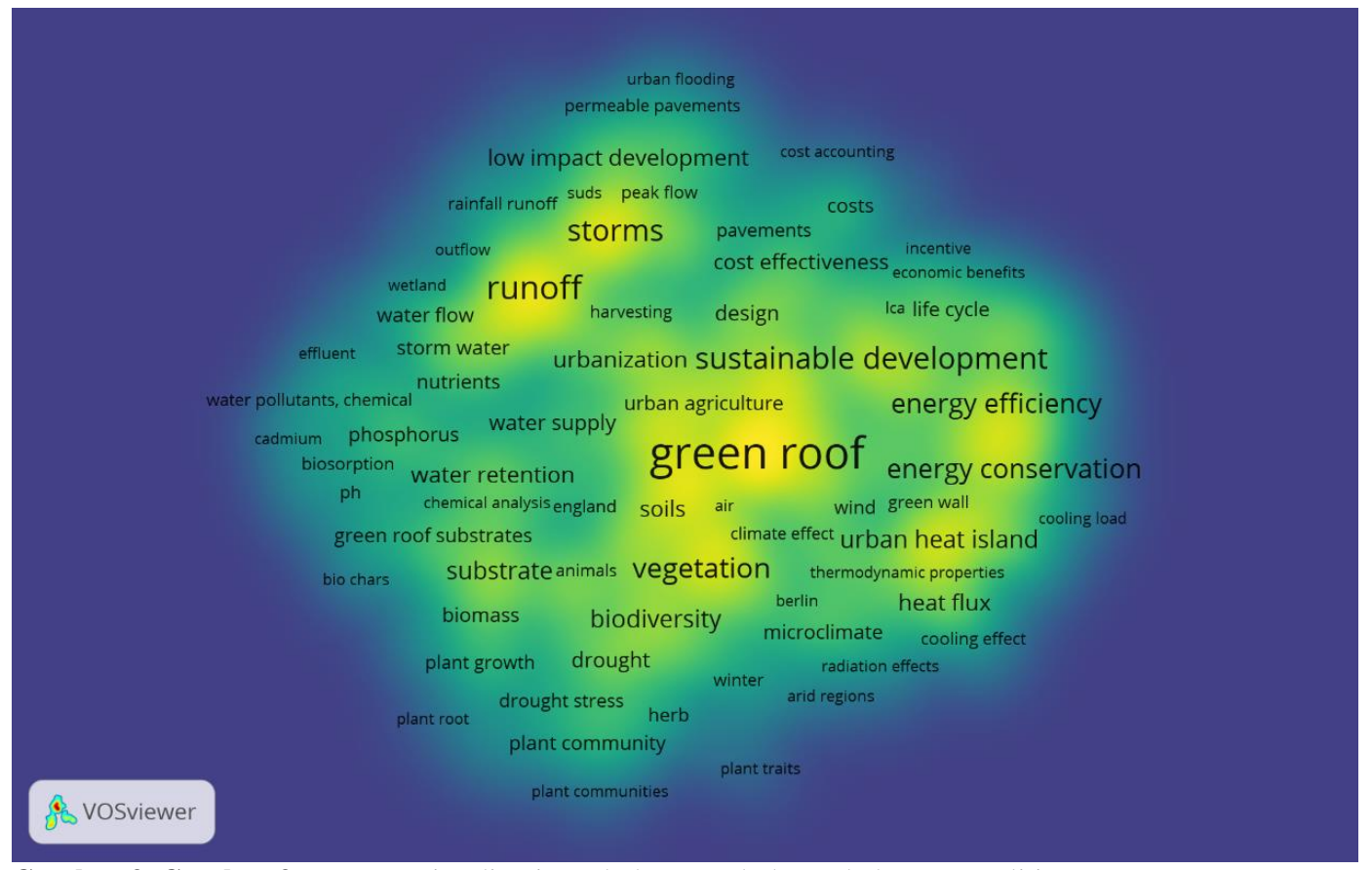

Gambar 3. Gambar 3. Density, visualisasi pembobotan pokok pembahasan penelitian 
Pada gambar 3, menjelaskan tentang gambaran bobot pokok penelitian. Pembobotan dalam skala warna biru ke kuning, semakin biru semakin rendah bobot pokok penelitian karena kurang banyak dibahas. Namun semakin kuning, menunjukkan pembobotan semakin tinggi.

Pemetaan teori berdasarkan vosviewer dengan pelbagai batasan kata kunci, judul dan konten dari abstrak, seperti pada gambar 1 menunjukkan beberapa celah yang masih berpeluang dilakukannya penelitian atap hijau. Hasil penelusuran dokumen dari kelima bidang kajian penelitian makro yang digunakan sebagai batasan penelusuran, ternyata belum banyak membahas tentang korelasi atap hijau pada aspek hunian, ruang produktif dan subtitusi ruang hijau. Pertimbangan lingkup detil pada aspek lingkungan, teknologi, hidrologi, sosial humaniora, permukiman dan ekonomi, belum banyak menghubungkan lokasi penelitian atap hijau di Indonesia. Pada gambar 1 visualisasi hubungan dari penelusuran referensi dengan vosviewer melalui konten judul dan abstrak artikel, semakin jelas menunjukkan kecenderungan penelitian atap hijau menuju pembangunan berkelanjutan dengan mempertimbangkan efisiensi energi, pelesatrian lingkungan dan permasalahan urban. Pada analisis vosviewer ini, walaupun banyak ditemukan pembahasan tentang lingkungan, namun masih sedikit ditemukan pembahasan atap hijau yang mencakup ketahanan pangan. Padahal secara mendunia, isu SDG's yang saat ini sedang menjadi orientasi utama masyarakat dunia, di antaranya mencakup ketahanan pangan. Oleh karenanya, tema atap hijau dengan upaya ketahanan pangan sangat penting dilakukan.

Penelitian atap hijau dari sudut pandang lain, diperoleh dokumen yang menggali prinsip dan konsep arsitektur hijau, paradigma arsitektur ramah lingkungan, arsitektur ekologis dan arsitektur hemat energi. GBCI (Green Building Council Indonesia) walaupun tidak secara khusus membahas atap hijau, namun telah merumuskan rating tools sebagai standar bangunan hijau untuk bangunan eksisting, bangunan baru, ruang terbuka publik, interior ruang dan rumah tinggal. Salah satu bagian dalam penilaiannya penggunaan material yang berkontribusi pada efisiensi energi. Namun pada detil penilaian belum secara spesifik mencakup aspek atap hijau. Penelitian tentang tingkat kepuasan hunian dengan atap hijau (Altomonte et al. 2017) menyampaikan bahwa pencapaian nilai IEQ
(Indoor Environment Quality) tidak secara signifikan meningkatkan kepuasan dengan faktor IEQ yang sesuai, sementara tingkat rating, maupun produk dan versi di mana sertifikasi telah diberikan, tidak mempengaruhi kepuasan tempat kerja. Penelitian ini tidak secara tegas menyatakan bahwa ketika sebuah bangunan mempunyai nilai "green" belum mampu menjadi tolok ukur kepuasan menghuni. Sementara itu (Catalano et al. 2018) melalui penelitian di wilayah Mediterania menyimpulkan bahwa pada pengetahuan saat ini pedoman/norma dengan mempertimbangkan kekhasan desain atap hijau harus disempurnakan secara luas. Kriteria yang termuat dalam greenship rating tools, SNI dan policy lainnya yang masih terbatas dipandang berpeluang untuk menjadi celah penelitian tentang atap hjiau. Oleh karenanya, perlu adanya penelitian untuk komponen pelengkap kriteria bangunan hijau. Komponen tersebut diantaranya meliputi nilai produktifitas atap hijau, kontribusi efisiensi energi atau nilai penurunan suhu pada atap hijau yang dapat diformulasikan pada parameter tolok ukur.

Model keseimbangan energi berbasis fisik dari atap bervegetasi telah dikembangkan dan diintegrasikan ke dalam program simulasi energi EnergyPlus. Penelitian tentang simulasi energi oleh Solana dkk (Molina-Solana et al. 2017) menerapkan Sains Data untuk mengatasi masalah yang paling sulit dihadapi oleh praktisi di bidang Manajemen Energi, terutama di 249ubtro bangunan. (L. Zhang et al. 2017) menggunakan perangkat lunak PHOENICS untuk membangun model bangunan 3D (tiga dimensi) dan mensimulasikan lingkungan termal di bawah kondisi hijau yang berbeda. Hasilnya menunjukkan perbedaan suhu permukaan bangunan di bawah kondisi atap hijau yang berbeda. Sementara Hale menggabungkan konsep dari Technology Acceptance Model (TAM) dengan Science and Technology Studies (STS) untuk membangun penggunaan energi bangunan hijau (Hale 2018). Lebih detil Hanssen dkk (Gram-Hanssen et al. 2018) mengembangkan simulasi atap hijau dengan fokus ada pada tiga fase: pengembangan teknologi bangunan baru, desain dan konstruksi bangunan, dan hunian.

Perangkat program uji simulasi dapat diterapkan untuk menganalisis implementasi atap hijau pada bangunan. Temuan penelitian ini dapat menjadi alat bantu yang penting untuk penelitian yang membutuhkan uji kinerja atap secara sistematis, cepat dan akurat. Hal ini menunjukkan 
terbukanya celah untuk melakukan penelitian atap hijau dengan cara eksperimen atau uji simulasi atau bahkan menggunakan keduanya dengan perbedaan metode.

Efisiensi energi pada bangunan hijau berkembang dari efisiensi energi bangunan ke arah efisiensi energi pada lingkungan (Hewitt et al. 2016). Perubahan ini akhirnya melibatkan masyarakat dalam mendukung keberlanjutan. Peran masyarakat diperlukan karena masih dirasakan sangat lemah. Untuk itu inovasi penyampaian pengetahuan dilakukan dengan pembelajaran sosial dengan motivasi dan tindakan edukasi menuju capaian keberhasilan bangunan hijau. Yan Zhang secara detil menambahkan peran perilaku penghuni dalam efektivitas membangun kebijakan efisiensi energi dipengaruhi oleh variabel sosial-ekonomi dan kebijakan (Y. Zhang et al. 2018). Pada pembahasan yang berbeda, penelitian tentang bangunan hijau pada hunian (Nilsson et al. 2018) menunjukkan bahwa dampak pada konsumsi energi sangat bervariasi di setiap rumah tinggal, menunjukkan bahwa rumah tinggal merespon umpan balik energi yang sangat individual. Hal ini menunjukkan peran masyarakat yang berbeda dalam konsumsi energi pada bangunan hijau. Selain peran masyarakat, diperlukan juga peran pemerintah (Irga et al. 2017), dalam penelitian yang dilakukan di Australia menunjukkan bahwa pengaruh pemerintah dapat memainkan peran penting dalam mendorong instalasi infrastruktur hijau. Hal senada disampaikan oleh Julie Cidell (Cidell 2017) melalui contoh atap hijau di Balai Kota Chicago. Penelitian tentang peran dikembangkan lagi oleh Meenakshi Sharma di India (Sharma 2018) dengan jelas menyatakan bahwa niat untuk mempertahankan tingkat kinerja hijau dan mengadopsi praktik hijau harus berasal dari semua lapisan masyarakat.

Masyarakat merupakan salah satu penentu keberlanjutan arsitektur hijau. Masyarakat secara umum sebagai penghuni bangunan rumah tinggal mempunyai peran pada keberlanjutan atap hijau (Yuliani and Setyaningsih 2018). Namun penelitian terkait tema atap hijau yang mengangkat tentang peran pada keberlanjutan atap hijau di Indonesia masih belum ada. Celah penelitian terdapat pada kriteria obyek bangunan untuk hunian, peluang ini cukup besar dengan pertimbangan prosentase hunian yang semakin meningkat mengikuti populasi penduduk dunia terutama di Indonesia.
Atap hijau dapat mengurangi konsumsi energi bangunan (Z. Zhang et al. 2018; Turski and Sekret 2018; Khoshbakht, Gou, and Dupre 2019) membuktikan bahwa potensi penghematan energi diperoleh karena faktor reduksi panas bangunan. Penelitian atap hijau yang dibandingkan dalam lingkungan kawasan (Darko and Chan 2018; Yang et al. 2018) menegaskan bahwa pemilihan bahan atap yang tepat berkontribusi pada pengurangan urban heat island, sedangkan atap hijau mampu memberikan penurunan panas kawasan. Elemen penutup atap hijau dapat memberikan kontribusi yang berbeda pada perbaikan lingkungan (Khabaz 2018), penggunaan semak mempunyai manfaat terhadap penurunan suhu permukaan atap sehingga terjadi efisiensi energi bangunan.

Atap hijau bermanfaat untuk pengelolaan efisiensi energi bangunan. Manfaat yang beragam dari atap hijau ini masih berkembang dengan pelbagai sudut pandang. Efisiensi energi dari atap hijau masih berpeluang menjadi tema penelitian arsitektural terkait dengan ruang-ruang produktif bangunan hunian.

Perbandingan atap hijau dan beton menunjukkan bahwa atap hijau berkontribusi terhadap pengurangan suhu bangunan. Hal yang sama disampaikan oleh Herrera dalam penelitian atap hijau di Spanyol (Herrera-Gomez, QuevedoNolasco, and Pérez-Urrestarazu 2017). Penelitian tentang kualitas lingkungan (Hellmeister and Richins 2019) menemukan atap hijau mengatasi gangguan ekosistem seperti polusi nutrisi. Penelitian atap hijau oleh Catalano dkk (Catalano et al. 2016) menyimpulkan bahwa atap hijau mampu memperbaiki komunitas tumbuhan regional dapat berfungsi sebagai model untuk rekrutmen dan instalasi benih. Vesuviano Stovin (Stovin, Vesuviano, and De-Ville 2017; AndrésDoménech et al. 2018) menggunakan model hidrologi langsung untuk mengeksplorasi dua pendekatan alternatif untuk mendeskripsikan kinerja penahanan: pendekatan probabilistik berdasarkan simulasi jangka waktu yang lama; dan pendekatan badai desain. Wong dan Jim (Wong and Jim 2017) mengevaluasi polusi pada iklim mikro yang dapat direduksi dengan atap hijau perkotaan di Hong Kong yang beriklim subtropis lembab. Hasil penelitian senada disampaikan oleh beberapa peneliti (Francis and Jensen 2017; Agra, Klein, Vasl, Kadas, et al. 2017; Liu et al. 2019). Atap hijau bermanfaat untuk memberikan kontrol kualitas lingkungan lebih baik. Penelitian ini sangat relevan dilakukan 
di Indonesia yang termasuk negara dengan tingkat polusi tinggi dan semakin tereduksinya ruang hijau, namun peneliti sejenis belum banyak dilakukan di Indonesia. Hal ini terlihat dari pemetaan penelitian berdasarkan lokasi, seperti pada gambar 4.

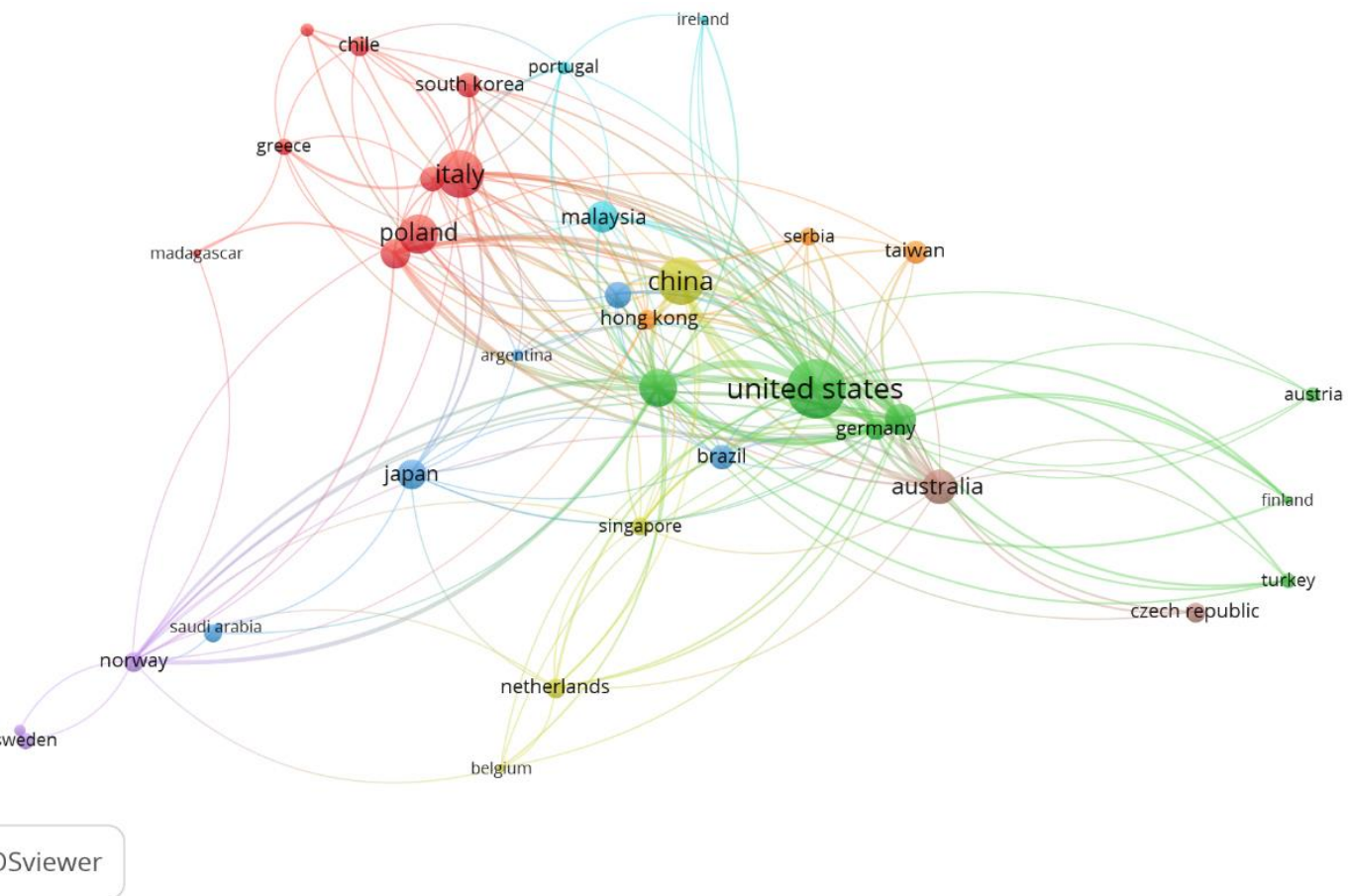

Gambar 4. Pemetaan riset berdasarkan lokasi

Sebaran lokasi penelitian atap hijau mencakup ke beberapa negara, dengan dominasi negara United State, China dan Italy. Sedangkan penelitian atap hijau di Indonesia tidak dapat terlacak, karena secara kuantitas kurang dari jumlah minimal pemetaan yakni 5 dokumen. Namun demikian, berdasarkan penelusuran secara manual dengan ekstensi waktu menjadi 2014 hingga 2020 dari dokumen penelitian pada jurnal terindex scopus, diperoleh dua penelitian atap hijau berlokasi di Indonesia, diuraikan secara ringkas pada tabel 1 .

Tabel 1. Penelitian atap hijau di Indonesia

\begin{tabular}{|c|c|c|}
\hline $\begin{array}{l}\text { Fokus } \\
\text { Pembahasan }\end{array}$ & $\begin{array}{l}\text { Lokasi } \\
\text { Tahun }\end{array}$ & Hasil \\
\hline $\begin{array}{l}\text { Implementasi } \\
\text { atap hijau pada } \\
\text { penurunan } \\
\text { urban heat } \\
\text { island kawasan } \\
\text { perkotaan. }\end{array}$ & $\begin{array}{l}\text { Semarang, } \\
2019 \\
\text { (Luthfiyyah } \\
\text { and Widjajanti } \\
\text { 2019). }\end{array}$ & $\begin{array}{l}\text { Peluang perbaikan } \\
\text { lingkungan dapat } \\
\text { dilakukan dengan } \\
\text { penerapan atap hijau } \\
\text { di koridor } \\
\text { perkotaan. }\end{array}$ \\
\hline
\end{tabular}

\begin{tabular}{|c|c|c|}
\hline $\begin{array}{l}\text { Fokus } \\
\text { Pembahasan }\end{array}$ & $\begin{array}{l}\text { Lokasi } \\
\text { Tahun }\end{array}$ & Hasil \\
\hline $\begin{array}{l}\text { Peran } \\
\text { masyarakat } \\
\text { dalam } \\
\text { keberlanjutan } \\
\text { atap hijau. }\end{array}$ & $\begin{array}{l}\text { Indonesia, } \\
2020 \\
\text { (Yuliani, } \\
\text { Hardiman, and } \\
\text { Setyowati } \\
\text { 2020). }\end{array}$ & $\begin{array}{l}\text { Apresiasi } \\
\text { masyarakat terhadap } \\
\text { manfaat atap hijau } \\
\text { sangat tinggi dan } \\
\text { sangat penting, } \\
\text { namun } \\
\text { implementasi atap } \\
\text { hijau di Indonesia } \\
\text { masih rendah, } \\
\text { sehingga perlu } \\
\text { upaya untuk } \\
\text { meningkatkan peran } \\
\text { masyarakat. }\end{array}$ \\
\hline
\end{tabular}

Penelitian atap hijau di Indonesia masih sangat terbatas, sehingga dengan mempertimbangkan peluang iklim tropis Indonesia, penelitian atap hijau berpeluang untuk dilakukan dalam disiplin arsitektur, meliputi konsep selubung bangunan, pengelolaan energi bangunan melalui rancangan model atap, dinding dan interior bangunan. 


\section{Kesimpulan}

Secara umum, peluang penelitian atap hijau meliputi empat komponen, yakni lokasi, obyek bangunan, eksplorasi manfaat dan bahan konstruksi. Secara detail, penelitian atap hijau berpeluang dapat dikembangkan pada disiplin arsitektur meliputi lokasi penelitian, penelitian menentukan lokasi di daerah tropis lembab, Indonesia. Lokasi ini merupakan lokasi yang sangat jarang diangkat dalam penelitian atap hijau. Selanjutnya, pembahasan pada obyek penelitian, difokuskan pada bangunan hunian. Penelitian atap hijau mempunyai target untuk menjadi substitusi ruang hijau dengan mempertimbangkan bahwa karakteristik peran penghuni rumah tinggal pada umumnya lebih peduli dengan ruang produktif dan elemen hijau yang diterapkan. Selain itu, secara kuantitas, kebutuhan hunian senantiasa meningkat seiring dengan populasi penduduk, sehingga berpotensi mengeliminasi ruang hijau.

Hal lain yang sangat penting dari sebuah penelitian atap hijau, yakni terkait dengan manfaat penelitian, atap hijau mengandung banyak manfaat yakni pada hidrologi, penurunan panas, energi, perbaikan lingkungan, hingga keragaman hayati. Melalui penelitian atap hijau kali ini, juga mendalami potensi ketahanan pangan, yakni ruang hijau menjadi ruang produktif untuk hunian bertingkat di permukiman pada kawasan perkotaan.

Penelitian atap hijau mempunyai peluang dalam menggunakan bahan bangunan dengan inovasi yang disesuaikan dengan kondisi setempat. Penelitian atap hijau yang fokus pada bahan konstruksi masih mempunyai celah yang dapat diteliti.

\section{Ucapan terimakasih}

Terimakasih kepada UPT Perpustakaan Universitas Diponegoro serta Program Doktor Ilmu Arsitektur dan Perkotaan, Universitas Diponegoro untuk semua dukungan sarana dan prasarana yang telah diberikan dalam menghimpun referensi untuk penelitian.

Terimakasih juga didedikasikan untuk Lembaga Penelitian dan Pengabdian pada Masyarakat (LPPM) Universitas Sebelas Maret Surkarta melalui anggaran hibah PNBP UNS tahun 2020 yang telah mendanai penelitian.

\section{Referensi}

Agra, Har'el, Tamir Klein, Amiel Vasl, Gyongyver Kadas, and Leon Blaustein. 2017. "Measuring the Effect of Plant-Community Composition on Carbon Fixation on Green Roofs." Urban Forestry and Urban Greening 24: $1-4$.

Agra, Har'el, Tamir Klein, Amiel Vasl, Hadar Shalom, Gyongyver Kadas, and Leon Blaustein. 2017. "Sedum-Dominated GreenRoofs in a Semi-Arid Region Increase CO2 Concentrations during the Dry Season." Science of the Total Environment 584-585.

Altomonte, Sergio, Stefano Schiavon, Michael G. Kent, and Gail Brager. 2017. "Indoor Environmental Quality and Occupant Satisfaction in Green-Certified Buildings." Building Research and Information, 1-20.

Andrés-Doménech, Ignacio, Sara PeralesMomparler, Adrián Morales-Torres, and Ignacio Escuder-Bueno. 2018. "Hydrological Performance of Green Roofs at Building and City Scales under Mediterranean Conditions." Sustainability

(Switzerland). https://doi.org/10.3390/su10093105.

Catalano, Chiara, Vito Armando Laudicina, Luigi Badalucco, and Riccardo Guarino. 2018. "Some European Green Roof Norms and Guidelines through the Lens of Biodiversity: Do Ecoregions and Plant Traits Also Matter?" Ecological Engineering 115 (December 2017): 15-26. https://doi.org/10.1016/j.ecoleng.2018.01.006

Catalano, Chiara, Corrado Marcenò, Vito Armando Laudicina, and Riccardo Guarino. 2016. "Thirty Years Unmanaged Green Roofs: Ecological Research and Design Implications." Landscape and Urban Planning 149: $\quad 11-19$. https://doi.org/10.1016/j.landurbplan.2016.01 .003 .

Cidell, Julie. 2017. "Sustainable Imaginaries and the Green Roof on Chicago's City Hall." Geoforum 86 (September): 169-76. https://doi.org/10.1016/j.geoforum.2017.09.0 16.

Darko, Amos, and Albert Ping Chuen Chan. 2018. "Strategies to Promote Green Building Technologies Adoption in Developing Countries: The Case of Ghana." Building and Environment 130 (December 2017): 74-84. 
https://doi.org/10.1016/j.buildenv.2017.12.02 2.

Francis, Lotte Fjendbo Møller, and Marina Bergen Jensen. 2017. "Benefits of Green Roofs: A Systematic Review of the Evidence for Three Ecosystem Services." Urban Forestry and Urban Greening 28 (April): 16776.

https://doi.org/10.1016/j.ufug.2017.10.015.

Gram-Hanssen, Kirsten, Susse Georg, Ellen Christiansen, and Per Heiselberg. 2018. "What next for Energy-Related Building Regulations?: The Occupancy Phase." Building Research and Information 46 (7): 790-803.

Hale, Lara Anne. 2018. "Anthropocentric Urban Sustainability: Human Signi Fi Cance in Building Automation" 42 (July 2017): $423-$ 33. https://doi.org/10.1016/j.scs.2018.07.024.

Hellmeister, Andr, and Harold Richins. 2019. "Green to Gold: Beneficial Impacts of Sustainability Certification and Practice on Tour Enterprise Performance," 1-17.

Herrera-Gomez, Sergio S., Abel QuevedoNolasco, and Luis Pérez-Urrestarazu. 2017. "The Role of Green Roofs in Climate Change Mitigation. A Case Study in Seville (Spain)." Building and Environment 123: 575-84.

Hewitt, Elizabeth L., Clinton J. Andrews, Jennifer A. Senick, Richard E. Wener, Uta Krogmann, and Maryann Sorensen Allacci. 2016. "Distinguishing between Green Building Occupants Reasoned and Unplanned Behaviours." Building Research and Information 44 (2): 119-34. https://doi.org/10.1080/09613218.2015.1015 854.

Hossain, Md Aslam, Shahriar Shams, Mahmud Amin, Md Sumon Reza, and Tanvir Uddin Chowdhury. 2019. "Perception and Barriers to Implementation of Intensive and Extensive Green Roofs in Dhaka, Bangladesh.” Buildings 9 (4). https://doi.org/10.3390/buildings9040079.

Hossain, Md Faruque. 2018. "Green Science: Advanced Building Design Technology to Mitigate Energy and Environment." Renewable and Sustainable Energy Reviews 81 (February 2017): 3051-60. https://doi.org/10.1016/j.rser.2017.08.064.

Irga, P. J., J. T. Braun, A. N.J. Douglas, T. Pettit, S. Fujiwara, M. D. Burchett, and F. R. Torpy. 2017. "The Distribution of Green Walls and Green Roofs throughout Australia: Do Policy
Instruments Influence the Frequency of Projects?" Urban Forestry and Urban Greening 24 (March): 164-74. https://doi.org/10.1016/j.ufug.2017.03.026.

Khabaz, Amjad. 2018. "Construction and Design Requirements of Green Buildings' Roofs in Saudi Arabia Depending on Thermal Conductivity Principle." Construction and Building Materials 186: 1119-31. https://doi.org/10.1016/j.conbuildmat.2018.0 7.234 .

Khoshbakht, M., Z. Gou, and K. Dupre. 2019. "Campus Green Buildings: Policy Implications for the Implementing, Monitoring and Evaluation of Campus Green Building Initiatives." IOP Conference Series: Earth and Environmental Science 294 (1). https://doi.org/10.1088/17551315/294/1/012004.

Liu, Wen, Wei Wei, Weiping Chen, Ravinesh C. Deo, Jianhua Si, Haiyang Xi, Baofeng Li, and Qi Feng. 2019. "The Impacts of Substrate and Vegetation on Stormwater Runoff Quality from Extensive Green Roofs." Journal of Hydrology 576. https://doi.org/10.1016/j.jhydrol.2019.06.061. Luthfiyyah, Dwi Nur, and Retno Widjajanti. 2019. "Green Roof to Overcome Urban Heat Island Effects in the Center of Semarang." E3S Web of Conferences 125 (201 9): 7-11. https://doi.org/10.1051/e3sconf/20191250701 8.

Molina-Solana, Miguel, Marïa Ros, M. Dolores Ruiz, Juan Gomez-Romero, and M. J. MartinBautista. 2017. "Data Science for Building Energy Management: A Review.” Renewable and Sustainable Energy Reviews 70 (November 2016): 598-609. https://doi.org/10.1016/j.rser.2016.11.132.

Morakinyo, Tobi Eniolu, K. W.D. Kalani, C. Dahanayake, Edward Ng, and Cheuk Lun Chow. 2017. "Temperature and Cooling Demand Reduction by Green-Roof Types in Different Climates and Urban Densities: A Co-Simulation Parametric Study." Energy and Buildings 145: 226-37. https://doi.org/10.1016/j.enbuild.2017.03.066

Morakinyo, Tobi Eniolu, Alan Lai, Kevin Ka Lun Lau, and Edward Ng. 2019. "Thermal Benefits of Vertical Greening in a High-Density City: Case Study of Hong Kong." Urban Forestry and Urban Greening 37 (November 2017): 
$42-55$.

https://doi.org/10.1016/j.ufug.2017.11.010.

Nilsson, Anders, Misse Wester, David Lazarevic, and Nils Brandt. 2018. "Smart Homes, Home Energy Management Systems and Real-Time Feedback: Lesson for Changing Energy Consumption Behavior from a Swedish Field Study." Submitted Manuscript 179: 15-25. https://doi.org/10.1016/j.enbuild.2018.08.026

Pradono, Budi. 2019. 'The Interiority of Proximity Between Nature and Architecture in Contemporary and Tropically Context with Cases Studies'. ARTEKS: Jurnal Teknik $\begin{array}{llll}\text { Arsitektur } & 3 & \text { (2): } & 129-44\end{array}$ https://doi.org/10.30822/arteks.v3i2.63.

Sharma, Meenakshi. 2018. "Development of a 'Green Building Sustainability Model' for Green Buildings in India." Journal of Cleaner Production 190: 538-51. https://doi.org/10.1016/j.jclepro.2018.04.154.

Stovin, Virginia, Gianni Vesuviano, and Simon De-Ville. 2017. "Defining Green Roof Detention Performance." Urban Water $\begin{array}{lll}\text { Journal } & 14 & \text { (6): }\end{array}$ https://doi.org/10.1080/1573062X.2015.1049 279.

Subroto, Tarcicius Yoyok Wahyu. 2019. 'Koeksistensi Alam Dan Budaya Dalam Arsitektur'. ARTEKS : Jurnal Teknik Arsitektur 3 (2). https://doi.org/10.30822/arteks.v3i2.60.

Sudradjat, Iwan. 2020. 'Teori Dalam Penelitian Arsitektur'. ARTEKS : Jurnal Teknik Arsitektur $\quad 5 \quad$ (1): https://doi.org/10.30822/arteks.v5i1.378.

Turski, Michał, and Robert Sekret. 2018. "Buildings and a District Heating Network as Thermal Energy Storages in the District Heating System." Energy and Buildings 179: 49-56.

U.S. Energy Information Administration. 2016. "World Energy Demand and Economic Outlook EIA's Handling of Non-U.S. Policies in the International Energy Outlook" 2016 (May 2016): 7-17. http://www.eia.gov/forecasts/ieo/world.cfm.

Widodo, Johannes. 2019. 'Human, Nature, And Architecture'. ARTEKS: Jurnal Teknik $\begin{array}{llll}\text { Arsitektur } & 3 & \text { (2): } 145-48 .\end{array}$ https://doi.org/10.30822/arteks.v3i2.65.

Wong, Gwendolyn K.L., and C. Y. Jim. 2017. "Urban-Microclimate Effect on Vector Mosquito Abundance of Tropical Green
Roofs." Building and Environment 112: 6376.

https://doi.org/10.1016/j.buildenv.2016.11.02 8.

World Wildlife Fund. 2016. "Annual Report WWF Indonesia 2016."

Yang, Junjing, Devi llamathy Mohan Kumar, Andri Pyrgou, Adrian Chong, Mat Santamouris, Denia Kolokotsa, and Siew Eang Lee. 2018. "Green and Cool Roofs' Urban Heat Island Mitigation Potential in Tropical Climate.” Solar Energy 173 (April): 597-609.

https://doi.org/10.1016/j.solener.2018.08.006.

Yuliani, Sri, Gagoek Hardiman, and Erni Setyowati. 2018. "ATAP HIJAU - Sebuah Kajian Asimilasi Budaya Berkebun Dan Bermukim Pada Rumah Tropis." Sabda 13 (2): 135-44.

-. 2020. "Green - Roof: The Role of Community in the Substitution of Green Space toward Sustainable Development," no. 2018. https://doi.org/10.3390/su12041429.

Yuliani, Sri, and Wiwik Setyaningsih. 2018. "The Community Role in Green Area Sustainability as a Model of Energy- Efficient Buildings in the Humid Tropical Region." In IOP Conference Series: Earth and Environmental Science. IOP Publishing.

Zhang, Linfang, Ming Jin, Jiying Liu, and Linhua Zhang. 2017. "Simulated Study on the Potential of Building Energy Saving Using the Green Roof." Procedia Engineering 205: 1469-76. https://doi.org/10.1016/j.proeng.2017.10.369.

Zhang, Yan, Xuemei Bai, Franklin P. Mills, and John C.V. Pezzey. 2018. "Rethinking the Role of Occupant Behavior in Building Energy Performance: A Review." Energy and Buildings 172: 279-94. https://doi.org/10.1016/j.enbuild.2018.05.017

Zhang, Zheng, Christopher Szota, Tim D. Fletcher, Nicholas S.G. Williams, Joerg Werdin, and Claire Farrell. 2018. "Influence of Plant Composition and Water Use Strategies on Green Roof Stormwater Retention." Science of the Total Environment 625: 775-81. https://doi.org/10.1016/j.scitotenv.2017.12.23 1. 